\title{
Pengaruh Bentuk Permukaan Heat Absorber Plate terhadap Temperatur dan Waktu Pengeringan pada Solar Dryer Kemiri
}

\author{
Mietra Anggara ${ }^{1}$, Rita Desiasni ${ }^{2}$ \\ Program Studi Teknik Mesin ${ }^{1}$, Program Studi Teknik Metalurgi², Universitas Teknologi \\ Sumbawa \\ Jl. Raya Olat Maras, Moyo Hulu Sumbawa Besar 84371, Indonesia \\ Email: mietra.anggara@uts.ac.id ${ }^{1}$, rita.desiasni@uts.ac.id
}

\begin{abstract}
Candlenut (Aleurites moluccana Wild) is an important versatile plant in Indonesia. Batulanteh Subdistrict, Batu Dulang Village is the highest candlenut producer in Sumbawa Regency, NTB with a land area of 595.7 ha and total production of 285.17 tons. Post-harvest candlenut handling at the farmer's level is still done traditionally where drying candlenuts on the floor or para-finished needs to be done with solar dryers. In this research, testing on absorbent plates is flat and corrugated as well as natural drying. The results showed that the corrugated heat absorber plate had the highest temperature average of $86.84 \mathrm{oC}$ with a drying time of 8 hours with the amount of hazelnut water content of $6.12 \%$. Making zinc absorbent plates is more effective and efficient used to dry candlenut in increasing the production of candlenuts.
\end{abstract}

Keywords: Candlenut, solar dryer, absorbent plate, candlenut water content.

\begin{abstract}
Abstrak
Kemiri (Aleurites moluccana Wild) adalah tanaman serbaguna yang penting di Indonesia. Kecamatan Batulanteh, Desa Batu Dulang adalah penghasil kemiri tertinggi di Kabupaten Sumbawa, NTB dengan luas lahan 595,7 ha dan total produksi 285,17 ton. Penanganan kemiri pasca panen di tingkat petani masih dilakukan secara tradisional dimana pengeringan kemiri di lantai atau parafin harus dilakukan dengan pengering surya. Dalam penelitian ini, dilakukan pengujian pada pelat penyerap datar dan bergelombang serta pengeringan alami. Hasil penelitian menunjukkan bahwa pelat penyerap panas bergelombang memiliki rata-rata suhu tertinggi $86,84{ }^{\circ} \mathrm{C}$ dengan waktu pengeringan 8 jam dengan jumlah kandungan air $6,12 \%$. Pelat penyerap seng lebih efektif dan efisien digunakan untuk mengeringkan kemiri dalam meningkatkan produksi kemiri.
\end{abstract}

Kata kunci: Kemiri, pengering surya, pelat penyerap, kadar air kemiri.

\section{Pendahuluan}

Kemiri (Aleurites moluccana Wild.) merupakan tanaman serbaguna yang penting di Indonesia. Kecamatan Batulanteh, Desa Batu Dulang merupakan penghasil kemiri tertinggi di Kabupaten Sumbawa dengan luas lahan sebesar 595.7 ha dan total produksi sebesar 285.17 ton [1]. Batulanteh sebagai penghasil kemiri di Kabupaten Sumbawa memiliki sekitar 60\% pengusaha yang mengelola lahan berupa kebun seluas lebih dari dua hektar per rumah tangga yang umumnya ditanami kemiri dan kopi. Inti kemiri telah digunakan untuk berbagai tujuan baik sebagai bahan dasar bumbu masak dan bahan farmasi. Biji kemiri tergolong buah batu karena berkulit keras menyerupai tempurung dengan permukaan luar yang kasar berlekuk. Tempurung biji ini tebalnya sekitar 3-5 $\mathrm{mm}$, berwarna coklat atau kehitaman. Kemiri yang bersumber dari suatu daerah memiliki tingkat kekerasan (firmness) yang berbeda dengan daerah yang lain [2].

Penanganan pasca panen kemiri di tingkat petani umumnya masih dilakukan 
secara tradisional dimana menjemur kemiri di lantai atau para-para dan pemecahan biji kemiri masih menggunakan alat pemecah sederhana. Cara tradisional kurang efektif dan efsien karena proses pengeringan kemiri masih bergantung pada sinar matahari dengan suhu rata-rata $36^{\circ} \mathrm{C}$, sehingga mereka membutuhkan waktu kurang lebih 7-9 hari untuk mendapatkan hasil pengeringan sesuai. Sedangkan seorang pekerja hanya mampu memecah kemiri 9-10 kg kemiri/hari [3]. Hal ini menimbulkan kelelahan kerja yang tinggi, di samping itu banyak inti yang pecah dan hancur (persentase inti bulat utuh hanya 40$60 \%$ ) sehingga harga kemiri menjadi lebih murah.

Pada proses produksi inti kemiri, tingkat kadar air sangat menentukan keutuhan dan kelengketan inti pada tempurung (cangkang) kemiri. Tingkat kadar air yang paling sesuai untuk proses pemecahan kemiri adalah 4 sampai $6 \%$ bk (basis kering). Hal ini didukung dengan bukti bahwa beberapa kerusakan kernel ditemukan dalam sampel dengan tingkat kadar air lebih rendah dari 3\% bk [4]. Waktu yang lama mempengaruhi mikroorganisme yang hidup dalam kemiri dan memungkinkan mikroorganisme merusak kualitas dari kemiri itu sendiri, sehingga dibutuhkan waktu yang lebih cepat untuk pengeringan. Dalam pengeringan kemiri dipengaruhi oleh intensitas radiasi matahari terhadap temperatur dan lama waktu pengeringan sesuai dengan kadar air kemiri yang dibutuhkan. Indonesia sebagai negara tropis yang berada pada garis khatulistiwa memiliki nilai radiasi matahari rata-rata 4.8 $\mathrm{kWh} / \mathrm{m}^{2} /$ hari [5]. Sehingga untuk mengeringkan kemiri dapat menggunakan tenaga radiasi matahari yaitu solar dryer. Dari permasalahan diatas maka perlu dilakukan penelitian tentang pengaruh heat absorber plate terhadap temperatur dan lama waktu pengeringan pada solar dryer kemiri.

\section{Metode Penelitian}

Penelitian ini merupakan penelitian eksperimental skala laboratorium yang bertujuan untuk mengetahui pengaruh heat absorber plate terhadap temperatur dan lama waktu pengeringan pada solar dryer kemiri.

\section{Bahan Penelitian}

Bahan penelitian yang digunakan adalah kemiri yang dikeringkan dengan pemanfaatan radiasi matahari. Selain itu untuk pelat penyerap yang digunakan dari bahan seng.

\section{Alat Penelitian}

Alat penelitian yang digunakan dalam penelitian ini adalah solar dryer dengan pelat penyerap jenis datar dan bergelombang. Spesifikasi alat sebagai berikut: Pelat penyerap seng tebal $0,4 \mathrm{~mm}$ jenis datar dan bergelombang dengan panjang pelat penyerap : $100 \mathrm{~cm}$, lebar pelat penyerap : $100 \mathrm{~cm}$, tinggi dinding bagian depan : $15 \mathrm{~cm}$, tinggi dinding bagian belakang : $34 \mathrm{~cm}$. Kaca penutup satu sisi tebal $3 \mathrm{~mm}$ dengan orientasi menghadap utara-selatan. Isolator dari bahan styreofoam dengan ketebalan $5 \mathrm{~cm}$. Sudut kemiringan kaca penutup $18^{\circ}$. Dinding menggunakan kaca bening $5 \mathrm{~mm}$.

\section{Variabel Penelitian}

Pada penelitian ini terdapat 3 variabel penelitian yang digunakan, yaitu variabel bebas, variabel terikat, dan variabel terkontrol. Variabel bebas adalah pelat penyerap jenis jenis datar dan bergelombang dari bahan seng. Variabel terikatnya adalah temperatur pelat penyerap $\left({ }^{\circ} \mathrm{C}\right)$, lama waktu pengeringan (jam), dan kadar air kemiri (\%). Sedangkan variabel terkontrolnya adalah kemiri yang diambil di desa Batu Dulang Kabupaten Sumbawa Besar. 


\section{Instalasi Penelitian}

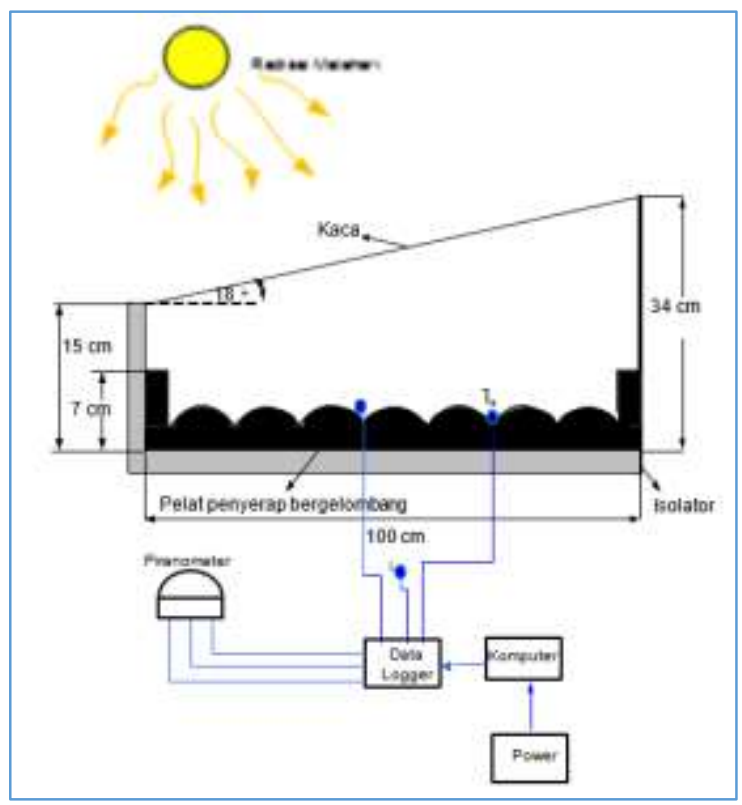

Gambar 1. Instalasi Penelitian

\section{Prosedur Pengambilan Data}

Pengambilan data dimulai pada pukul 10.00 sampai dengan pukul 14.00 WITA dalam kondisi cuaca cerah dengan prosedur sebagai berikut.

Tahap awal meletakkan 2 buah alat solar dryer di bawah radiasi matahari secara langsung dan memposisikannya sesuai dengan arah matahari untuk daerah Sumbawa dengan posisi $9,7^{\circ}$ LS dan 118,22 ${ }^{\circ}$ BT untuk tanggal $1-31$ Juli 2018. Posisi matahari akan cenderung pada Lintang Utara, sehingga alat solar dryer diposisikan menghadap utara-selatan. Kemudian kemiri dimasukkan ke dalam alat solar dryer dengan jumlah yang yang sudah ditentukan yaitu $5 \mathrm{~kg}$, tidak dilakukan penambahan kemiri dalam jangka waktu satu hari. Untuk mengetahui jumlah kadar air pada kemiri yang berkurang dalam waktu satu hari. Selanjutnya melakukan pengukuran bertahap setiap selang waktu 1 jam terhadap intensitas radiasi matahari, temperatur lingkungan, dan temperatur pelat penyerap. Kemudian mengukur jumlah kadar air kemiri yang berkurang selama satu hari. Tahap akhir melakukan pengulangan pengujian untuk mendapatkan hasil yang optimal.

\section{Hasil dan Pembahasan}

\section{Pengambilan data pertama pada pelat penyerap datar dan bergelombang terhadap intensitas radiasi matahari}

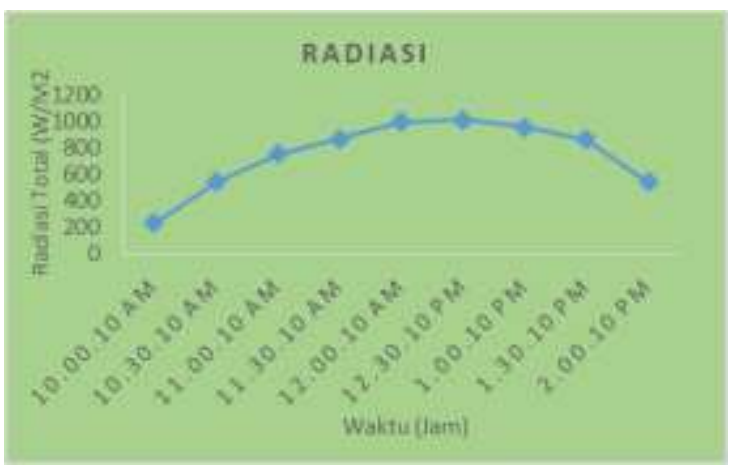

(a)

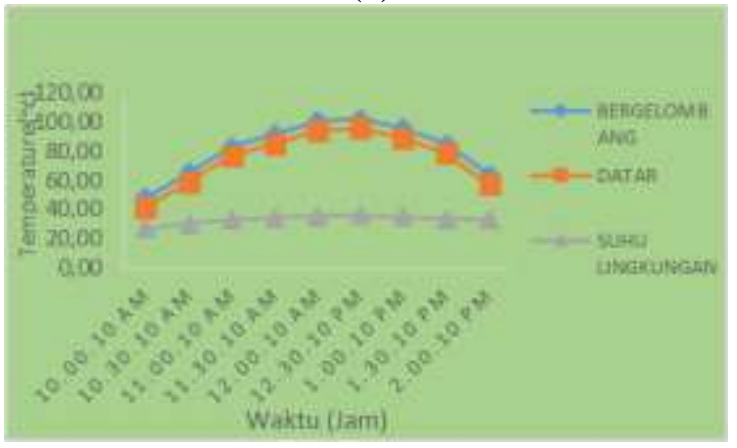

(b)

Gambar 2. a) Intensitas radiasi matahari, b)

Pelat penyerap jenis datar dan bergelombang

Untuk dapat mengetahui kemampuan penyerapan panas radiasi matahari yang dilakukan oleh alat solar dryer, dapat kita tinjau melalui radiasi matahari yang diterima diubah menjadi energi panas pada plat penyerap. Energi panas yang diubah tersebut menjadi energi berguna yang digunakan untuk mengeringkan kemiri dapat kita lihat pada gambar di atas.

Pada pengambilan data pertama gambar (a) radiasi matahari yang direkam oleh data logger menggunakan pyranometer selama pengujian cukup tinggi. Radiasi total yang diterima mulai pukul 10.00 WITA naik perlahan-lahan kemudian akan mencapai puncaknya antara pukul 11.00 sampai dengan pukul 13.00. 
Setelah itu radiasi matahari yang diterima mengalami penurunan secara perlahan hingga pukul 14.00. Radiasi matahari total yang diterima oleh pyranometer bervariasi yaitu $233,34 \mathrm{~W} / \mathrm{m}^{2}$ pada pagi hari, 1012,07 $\mathrm{W} / \mathrm{m}^{2}$ pada siang hari dan $546,63 \mathrm{~W} / \mathrm{m}^{2}$ pada sore hari. Sehingga rata-rata radiasi matahari yang diterima pada alat solar dryer $753,22 \mathrm{~W} / \mathrm{m}^{2}$.

Pada gambar (b) Temperatur pelat penyerap seng jenis datar dan bergelombang mengalami proses pengeringan pada kemiri. Karena intensitas radiasi matahari diserap oleh pelat penyerap kemudian memanaskan pelat penyerap seng. Sehingga kemiri mengalami pemanasan dan penurunan kadar air. Intensitas radiasi matahari untuk setiap waktunya berbeda, hal ini disebabkan kondisi cuaca berawan atau mendung. Intensitas radiasi matahari yang diterima oleh solar dryer berpengaruh terhadap temperatur dan lama waktu pengeringan kemiri. Karena semakin besar intensitas radiasi matahari yang diserap oleh pelat penyerap menunjukkan semakin besar energi yang diterima oleh pelat penyerap yang digunakan untuk mengeringkan kemiri di dalam solar dryer. Sehingga dengan peningkatan intensitas radiasi matahari dapat meningkatkan temperatur dan lama waktu pengeringan kemiri.

Pada gambar 2 (a) dan (b) yaitu instensitas radiasi matahari terhadap penyerapan panas pada pelat penyerap seng jenis datar dan bergelombang menunjukkan bahwa rata-rata panas yang digunakan untuk mengeringkan kemiri mengalami pola yang sama dengan intensitas radiasi matahari. Karena intensitas radiasi matahari penyebab utama dalam mempengaruhi naik turunnya kalor yang diterima oleh pelat penyerap. Pada gambar 2 (b) terlihat bahwa temperatur pelat penyerap seng jenis bergelombang memiliki temperatur lebih besar yaitu rata-rata $81,96^{\circ} \mathrm{C}$ sedangkan pada pelat penyerap seng jenis datar memiliki temperatur yaitu rata-rata $75,46^{\circ} \mathrm{C}$. Hal ini disebabkan oleh permukaan pelat penyerap jenis bergelombang yang mampu menyerap radiasi matahari dan memindahkan ke kemiri dengan baik dibandingkan dengan pelat datar. Selain itu pantulan radiasi matahari pada pelat penyerap bergelombang diteruskan ke samping pelat penyerap dan kemiri sehingga panas bertambah. Berbeda dengan pelat datar yang memantulkan radiasi matahari ke dinding dan atas pelat penyerap sehingga panas yang diterima berkurang.

\section{Pengambilan data kedua pada pelat penyerap datar dan bergelombang terhadap intensitas radiasi matahari}

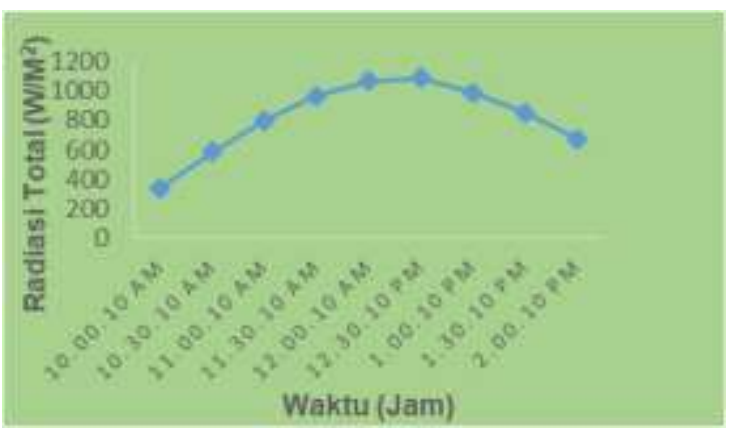

(a)

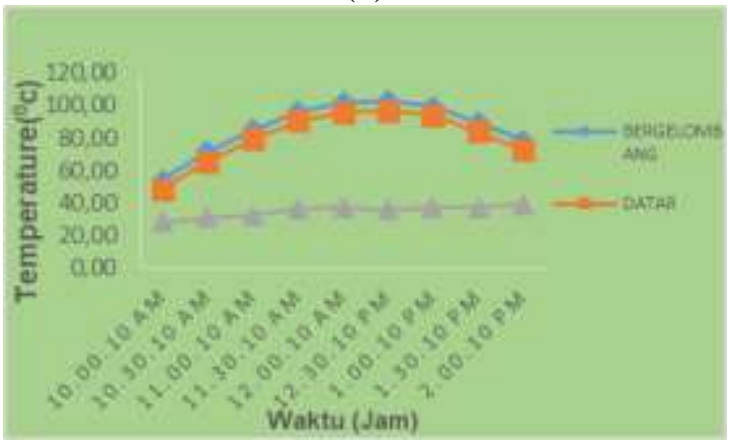

(b)

Gambar 3. a) Intensitas radiasi matahari, b) Pelat penyerap jenis datar dan bergelombang

Pada pengambilan data kedua gambar (a) radiasi matahari yang direkam oleh data logger menggunakan pyranometer selama pengujian mengalami peningkatan dibandingkan dengan pengambilan data radiasi pertama. Radiasi matahari total yang diterima oleh pyranometer yaitu pada pagi hari $341,34 \mathrm{~W} / \mathrm{m}^{2}$, pada siang hari 1091,07 $\mathrm{W} / \mathrm{m}^{2}$ dan pada sore hari $677,63 \mathrm{~W} / \mathrm{m}^{2}$. Sehingga rata-rata radiasi matahari yang diterima pada alat solar dryer $820,22 \mathrm{~W} / \mathrm{m}^{2}$. 
Pada gambar 3 (a) dan (b) yaitu instensitas radiasi matahari terhadap penyerapan panas pada pelat penyerap seng jenis datar dan bergelombang menunjukkan bahwa rata-rata panas yang digunakan untuk mengeringkan kemiri mengalami pola yang sama dengan intensitas radiasi matahari. Karena intensitas radiasi matahari penyebab utama dalam mempengaruhi naik turunnya kalor yang diterima oleh pelat penyerap. Pada gambar 3 (b) terlihat bahwa temperatur pelat penyerap seng jenis bergelombang mengalami peningkatan temperatur seiring dengan peningkatan radiasi matahari yaitu rata-rata $86,84^{\circ} \mathrm{C}$ sedangkan pada pelat penyerap seng jenis datar memiliki temperatur yaitu rata-rata $80,84^{0} \mathrm{C}$.

\section{Hasil Pengujian Kadar Air Kemiri Terhadap Waktu}

Tabel 1. Hasil uji kadar air (\%) terhadap waktu

\begin{tabular}{ccccc}
\hline No & Waktu & Bergelombang & Datar & Alami \\
\hline 1 & 0 & 10.38 & 10.38 & 10.38 \\
\hline 2 & 4 & 8.15 & 8.73 & 9.89 \\
\hline 3 & 8 & 6.12 & 6.74 & 8.83 \\
\hline 4 & 12 & 5.22 & 5.82 & 7.37 \\
\hline 5 & 16 & 4.46 & 4.86 & 6.58 \\
\hline
\end{tabular}

Pada Tabel 1, hasil pengujian kadar air terhadap waktu terlihat variasi kadar air yang berbeda terhadap jenis pelat penyerap yang digunakan dalam mengeringkan kemiri. Berdasarkan hasil dari penelitian oleh Tarigan et al pada tahun 2007 [4], bahwa tingkat kadar air yang dikeringkan paling sesuai untuk proses pemecahan kemiri adalah 4 sampai 6\% bk. Pada Tabel 1 terlihat bahwa pengeringan kemiri dengan menggunakan pelat penyerap seng bergelombang memiliki kadar air terendah $6,12 \%$ dengan lama pengeringan selama 8 jam. Berbeda dengan pelat penyerap datar yaitu $6,74 \%$ dan pengeringan alami yaitu $8.83 \%$. Hal ini menyebabkan pelat penyerap seng bergelombang dalam waktu 8 jam dengan rata-rata temperatur 86,84 mampu mengeringkan kemiri dengan jumlah kadar yang sesuai untuk segera dilakukan pemecahan. Sehingga pelat penyerap seng bergelombang efektif dan efisien digunakan untuk mengeringkan kemiri dalam meningkatkan produksi kemiri.

\section{Kesimpulan}

Pada heat absorber plate seng jenis bergelombang memiliki temperature tertinggi rata-rata $86,84{ }^{\circ} \mathrm{C}$ dengan lama waktu pengeringan selama 8 jam dengan jumlah kadar air kemiri 6,12 \%. Sehingga pelat penyerap seng bergelombang lebih efektif dan efisien digunakan untuk mengeringkan kemiri dalam meningkatkan produksi kemiri.

\section{Referensi}

[1]. BPS, 2009. Propinsi dalam Angka. Badan Pusat Statistik Propinsi Nusa Tenggara Barat

[2]. Pedoman budidaya kemiri (aleurites molucana wild) Departemen Pertanian. Direktorat Jenderal Perkebunan Indonesia, 2006.

[3]. Darmawan, S., R. Kurniadi. 2007. Studi pengusahaan kemiri di Flores NTT dan Lombok NTB. Info Sosial Ekonomi Vol.7 (2) Juni 2007: 117-129.

[4]. Tarigan, E., G. Prateepchaikul, R. Yamsaengsung, A. Sirichote, P. Tekasakul. 2007. Drying characteristics of unshelled kernels of candle nuts. Journal of Food Engineering. 79: 828833.

[5]. Ghalya Pikra, 2018, Pengaruh Intensitas Radiasi Matahari Terhadap Potensi Listrik Yang Dihasilkan Pada Sistem Solar Collector Di Indonesia, LIPI: Jakarta 